\title{
West Germany admits it knew of Libyan chemical plant
}

\section{Paris}

MORE evidence emerged last week that West German companies have been involved in the construction of an alleged chemical arms plant at Rabta, Libya, bringing a vigorous attack in the West German Bundestag (parliament) on 18 January of the federal government's handling of the affair.

Chancellor Helmut Kohl was accused of damaging West Germany's relationship with the United States, bringing shame upon the Bundestag, prolonging the threat of chemical arms and covering up the involvement of West German com-

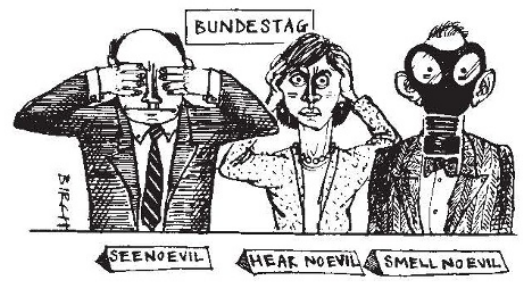

panies in their manufacture.

For seven months, Kohl's government had shrugged off increasingly noisy US claims that Libya was building a chemical arms factory, and that West German companies were involved (see Nature 337, 199; 19 January 1989). But last week Chancellery chief Wolfgang Schäuble admitted to the Bundestag that both allegations were justified.

Schäuble confirmed that the government had been aware since May 1988 of the possible involvement of West German companies in building and supplying the factory. But he defended the government's silence, saying that customs investigations of one company, ImhausenChemie $\mathrm{GmbH}$, had failed to produce sufficient evidence for a prosecution.

Last July, West German customs officials were warned by foreign intelligence agencies that a Frankfurt-based company, Ihsan Barbouti International (IBI), was suspected of engineering an illegal supply route to divert construction materials and chemicals to Libya. But it is only this year that documents seized from IBI offices have confirmed the clandestine operations. The company is now in liquidation.

IBI, set up by Iraqi businessman Ihsan Barbouti, used a Hong Kong company that was also linked with ImhausenChemie to obtain legitimate export licences. But cargoes that included architectural plans from Imhausen-Chemie and ventilation equipment and dichloroethane from two other German suppliers were diverted to Libya.

Legal action is now being taken against IBI for falsification of export documents. But it is still uncertain whether the suppliers, including Imhausen-Chemie, Merck and Alfred Tewes $\mathrm{GmbH}$, actually broke the law.

Despite tighter controls, the volume of export trade - about 2.5 million shipments a month from West Germany makes it impossible to halt illegal trading completely. Now other governments are looking to see if they can point an untainted finger at West Germany.

Peter Coles

\section{Japan denies involvement in Libya}

Tokyo

JAPAN's Foreign Ministry has firmly denied a US claim that two Japanese companies provided Libya with equipment for a chemical weapons plant. According to the spokesman, Yoshifumi Matsuda, the disputed "metallurgical complex" built in Libya by Japan Steel Works was designed to produce parts for a water purification plant, not shells for chemical weapons as had been claimed.

Allegations about Japan Steel Works and another company, Marubeni, hit the Japanese headlines last week after US Senator Jesse Helms included their names in a list of 36 companies, most of them West German, which he submitted to the Senate Foreign Relations Committee. All were alleged to have had links to the Libyan plant.

But Matsuda says that Senator Helms's list is based only on newspaper articles. In December, the Christian Science Monitor mentioned Japan Steel Works in an article on chemical warfare. The Ministry of International Trade and Industry (MITI) has since had time to investigate the allegations and found them to be untrue.

According to a MITI spokesman, a close watch is kept on products that might be used to build chemical weapons, and the export of nine key chemicals from Japan is prohibited without special licence.

Alun Anderson

\section{AIDS test law}

BULgaria has introduced tough new legislation aimed at halting the spread of AIDS. Unlike other socialist countries, where anti-AIDS legislation concentrates on curbing the sexual activity of people known to be HIV-positive, the Bulgarian law concentrates on compulsory testing and treatment. Heavy fines will be imposed on those who refuse tests, and also "persons who do not fulfil their official duties in the fight against AIDS".

\section{Another blow for creationism in California}

\section{Berkeley}

THE California Board of Education has passed a policy statement on the teaching of science aimed at strengthening the message that evolution, not creationism, belongs in the science classroom. The statement supersedes a vague "antidogmatism policy" which often left teachers uncertain about how strongly they should stress evolution.

The antidogmatism statement, adopted in 1972 when Ronald Reagan was governor, was a brief directive on the discussion of "origins of life and earth", that required that "dogmatism be changed to conditional statements where speculation is offered as explanation for origins". California creationists, including members of the Institute for Creation Research in San Diego, have used the statement in their efforts to water down the teaching of evolution in California classrooms.

In 1981, a Superior Court judge decided against creationists in a case challenging the teaching of evolution as dogmatic. His decision affirmed that teaching of the scientific method is by definition not dogmatic, and that teaching of creation in public schools constitutes religious instruction, and is therefore constitutional.

But he upheld the antidogmatism policy as the ruler against which science education was to be measured. Scientists and teachers complained that the policy singled out the theory of evolution as somehow little more than conjecture, ignoring the true definition of a scientific theory and the fact that all science is based on theories that have stood the test of time. Many teachers, they said, felt compelled by the policy to couch their discussions of evolution in speculative terms.

The new policy statement carefully defines theories as tools of science, different from beliefs because they are logical constructs based on evidence, and subject to testing, modification and refutation. Beliefs, it implies, are closer to dogma, as they are based on ideology and not subject to test. A spokesman for the education board says that by requiring science teachers to teach only what falls within the definition of science, and directing administrators to support teachers in their resistance against pressure to do otherwise, the statement's drafters hope that it will provide firm support for science teachers who are put under pressure to teach creation in their classes.

The board is also planning to reject for use in California classrooms textbooks that do not deal adequately with evolution. Marcia Barinaga 